\title{
INDUCTION MOTOR ROTOR CAGE FAULTS AS IGNITION SOURCES OF EXPLOSIVE ATMOSPHERE - RESEARCH ON HEATING
}

\author{
Ivica Gavranić, Mario Vražić, Damir Sumina
}

Original scientific paper

This paper discusses the risks of ignition sources of electric motors in areas at risk of explosive atmospheres. The basis for this work is research on the occurrence of the source of ignition resulting from an induction motor rotor cage fault. The research was targeted at the heating effects on the rotor cage of the "Ex e" type of protection motor, as a result of different levels of rotor damage. The main presumption that specific rotor cage faults could become effective sources of ignition was empirically verified. Results of this research provide a deeper insight into the possibilities and risks of the occurrence of ignition sources in explosive atmospheres caused by hot spots generated in the rotor cage due to hidden faults. An important result of this research is the realization that a traditional approach to the analysis of explosion protection is not sufficient in identifying these faults.

Keywords: explosion protection; ignition; induction motor; rotor fault; technical diagnostics

Kvarovi kaveza rotora elektromotora kao uzročnici paljenja eksplozivne atmosfere - istraživanje zagrijavanja

Izvorni znanstveni članak

U radu se razmatraju rizici pojave uzročnika paljenja unutar elektromotora u prostorima ugroženim eksplozivnom atmosferom. Istraživanje pojave uzročnika paljenja zbog oštećenja kaveza rotora asinkronog motora temeljni je dio ovog rada. Istraživana su zagrijavanja kaveza rotora protueksplozijski zaštićenog "Ex e" motora kod različitih razina oštećenja. Ispitivanjima je potvrđena pretpostavka da bi određeni kvarovi kaveza rotora mogli biti djelotvorni uzročnici paljenja. Rezultatima istraživanja produbljene su spoznaje o mogućnostima i rizicima pojavljivanja uzročnika paljenja eksplozivne atmosfere stvaranjem vrućih površina zbog kvarova u kavezu rotora. Spoznaja da tradicionalni pristup analize protueksplozijske zaštite nije dostatan za otkrivanje spomenutih kvarova važan je rezultat ovog rada.

Ključne riječi: asinkroni motor; kvar rotora; paljenje; protueksplozijska zaštita; tehnička dijagnostika

\section{Introduction}

Modern technologies utilized in industry commonly involve the risks of explosive atmospheres (e.g. oil and gas exploitation, chemical, pharmaceutical, etc.). In order to protect people and the environment, the highest safety standards are required in industrial plants designed for operation in explosive atmospheres. Risk analysis and assessment in such plants should consider every situation or effect which can occur and result in the generation of an ignition source and/or the formation of an explosive atmosphere. A simultaneous occurrence of the ignition source and explosive atmosphere poses a serious risk which can lead to an explosion.

Today's plants at risk of explosive atmospheres are equipped with a large number of electric motor drives (EMD). Use of such drives in explosive atmospheres increases the risk of occurrence of ignition sources (e.g. overheating). A typical structure of EMD in the area at risk of explosive atmosphere is shown in Fig. 1 [1].

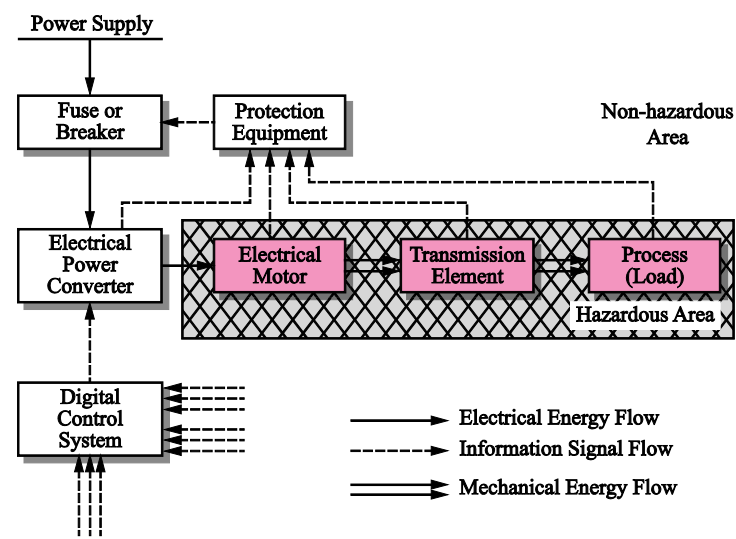

Figure 1 EMD in a hazardous area
This paper considers the induction motor as a central part of an EMD in a hazardous area and as one of the most important potential sources of ignition. Fig. 2 shows the contribution of different sources of ignition in U.K. on-shore non-process areas [2].

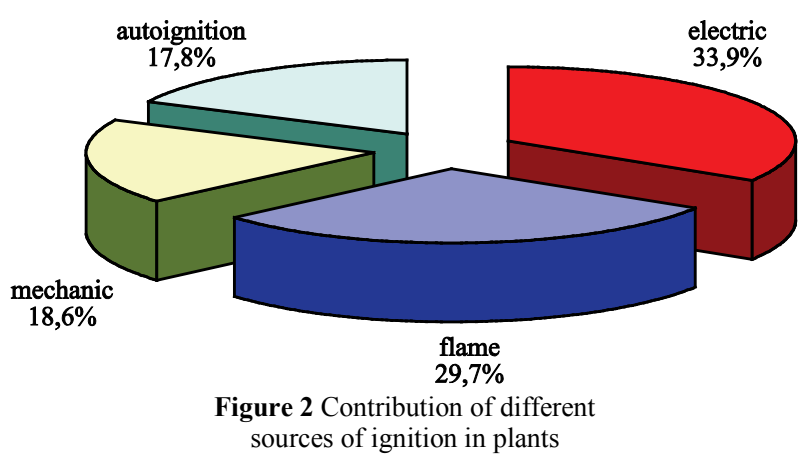

Fig. 2 shows clear evidence that electrical sources are the most frequent independent sources of ignition, and the induction motor is one of them. Fig. 3 shows contribution of specific faults in induction motors [3]. Rotor and stator winding faults are declared as frequent faults (around 45 $\%$ of the total number of faults in induction motors) $[4,5]$.

In majority of cases, rotor faults described above cannot be easily identified during the normal operation of the motor. Furthermore, those faults cannot even be identified by the use of essential test methods for explosion protected motors, which are normally applied in traditional approach to explosion protection.

To detect these faults, diagnostic motor tests need to be applied, including tests to determine rotor cage condition. Diagnostic tests applied on explosion protected motors (e.g. on rotor cage) are no different than diagnostic tests applied to standard design motors and are 
described in detail in literature and scientific papers, therefore are not described again in this paper.

Diagnostics on induction motor based on spectral analysis of stator current is a commonly used method for determination of rotor cage condition $[6 \div 8]$.

Diagnostics based on the analysis of acoustic signal is proposed in $[9 \div 11]$.

In $[12 \div 16]$ authors showed and proposed these and some other diagnostic methods (e.g. time frequency representation algorithm, changing of magnetic flux density distribution etc.) for detection of motor faults, especially rotor faults.

Just the fact that rotor faults are amongst the most important ones and are difficult to detect with routine test methods was the main reason to conduct the detailed research of rotor faults as potential sources of ignition of explosive atmospheres.

In order to detect, effectively and on time, rotor faults leading to the occurrence of source of ignition, technical diagnostics shall often be applied (e.g. spectral analysis of stator current, conductivity measurement on bars and rings etc.).
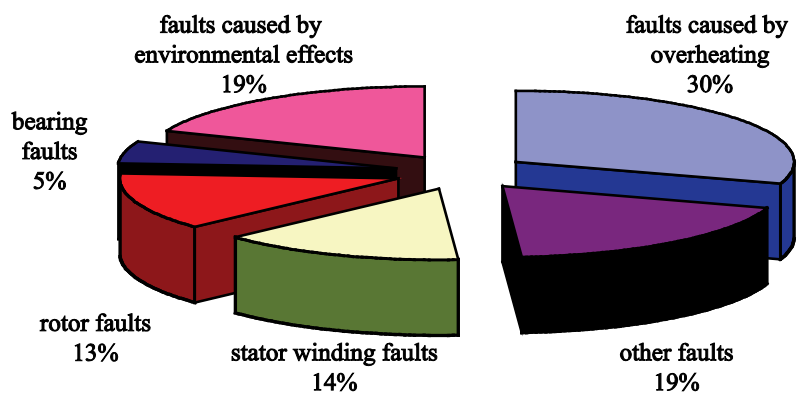

Figure 3 Contribution of specific faults in induction motors

The central part of this work is the research into the possibility of the generation of effective ignition sources in the form of hot surfaces due to fault conditions of the induction motor rotor. The fault condition in the rotor cage does not necessarily lead to a formation of an effective ignition source. Fig. 4 shows a typical curve of a progressive fault. It is clear from this curve that only a specific level of fault leads to an effective ignition source.

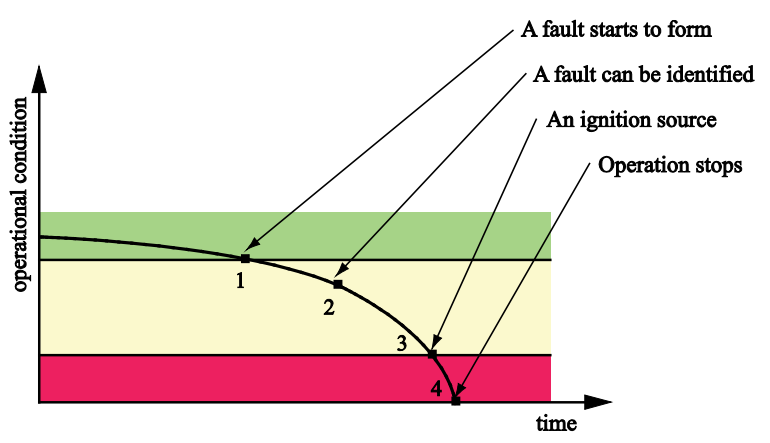

Figure 4 A curve of a progressive fault

In hazardous areas, special care needs to be applied to periodic inspections of induction motors to allow for the detection of faults which could lead to an effective source of ignition. Such faults should be detected in their initial phase or, at the latest, before they reach the level where they change from a potential to an effective source of ignition.

\section{Traditional approach to explosion protection}

Led by the idea of avoiding and/or reducing the risk of explosions by preventing the simultaneous occurrence of an explosive atmosphere and an ignition source, today's methodology aiming at ensuring explosion protection in electrical drives is based on the application of electrical motors specifically designed and built for use in areas where the occurrence of explosive atmospheres is possible.

In Europe prevention of explosions is based on the European Directives (ATEX Directives) [17 $\div 19]$.

The traditional way of ensuring explosion protection of motors in areas at risk of explosive atmospheres, specified in the abovementioned ATEX Directives, is based on the use of motors which ensure certain equipment protection levels (EPLs Ga, Gb or Gc), that is they fulfil requirements of a certain category (1, 2 or 3 ). Compliance of a motor with the required category and equipment protection levels (EPLs) is achieved by constructing a motor with a certain type of protection.

Characteristics of a hazardous area define the requirements of motors with the appropriate equipment protection levels (EPLs) or category must meet. Hazardous areas are divided into three zones; zone 0 , zoneland zone 2 [20]. The basic characteristics of each hazardous area (with regard to the possible occurrence of an explosive atmosphere and its expected duration) are briefly illustrated in Tab. 1.

Table 1 Characteristics of zone 0,1 and 2

\begin{tabular}{|c|c|c|}
\hline Zone & $\begin{array}{c}\text { Possible occurrence of } \\
\text { explosive atmosphere }\end{array}$ & Expected duration \\
\hline 0 & Normal operation & $\begin{array}{c}\text { Continuously, for long } \\
\text { periods or frequently }\end{array}$ \\
\hline 1 & $\begin{array}{c}\text { Likely to occur } \\
\text { in normal operation }\end{array}$ & Occasionally \\
\hline 2 & $\begin{array}{c}\text { Not likely to occur } \\
\text { in normal operation }\end{array}$ & Short period only \\
\hline
\end{tabular}

Safety levels provided by motors with certain equipment protection levels (categories) can be basically demonstrated according to Tab. 2 .

Table 2 Motor protection levels

\begin{tabular}{|c|c|c|}
\hline $\begin{array}{c}\text { EPLs } \\
\text { (Cat.) }\end{array}$ & Level of protection & Source of ignition \\
\hline $\begin{array}{c}\text { Ga } \\
(1)\end{array}$ & Very high & $\begin{array}{c}\text { Not in normal operation and } \\
\text { not in expected rare } \\
\text { malfunctions }\end{array}$ \\
\hline $\begin{array}{c}\text { Gb } \\
(2)\end{array}$ & High & $\begin{array}{c}\text { Not in normal operation and } \\
\text { not in expected malfunctions } \\
\text { which are taken into } \\
\text { consideration }\end{array}$ \\
\hline $\begin{array}{c}\text { Gc } \\
(3)\end{array}$ & Enhanced & Not in normal operation \\
\hline
\end{tabular}

Selection of motors depending on zones and permitted equipment protection level (category) are illustrated in Tab. 3.

The traditional approach to explosion protection is based on a special construction of equipment which makes it suitable for use in hazardous areas. As to induction motors, there are many international standards available listing special test methods related to specific 
explosion protection techniques. These basic tests are primarily performed during the process of certification of induction motors and partly during regular maintenance procedures.

Table 3 Permitted equipment categories / equipment protection levels (EPLs) depending on zones

\begin{tabular}{|c|c|c|}
\hline Zone & $\begin{array}{c}\text { EPLs } \\
\text { (permitted categories) }\end{array}$ & $\begin{array}{c}\text { Permitted type } \\
\text { of motor protection }\end{array}$ \\
\hline 0 & $\begin{array}{l}\mathrm{Ga} \\
(1)\end{array}$ & $\begin{array}{l}\text { Theoretical: Two independent } \\
\text { types of protection. } \\
\text { (e.g. "Ex e" + "Ex d") }\end{array}$ \\
\hline 1 & $\begin{array}{l}\text { Ga or } \mathrm{Gb} \\
(1 \text { or } 2)\end{array}$ & $\begin{array}{l}\text { "Ex d", "Ex e", } \\
\text { "Ex px", "Ex py" }\end{array}$ \\
\hline 2 & $\begin{array}{c}\mathrm{Ga}, \mathrm{Gb} \text { or } \mathrm{Gc} \\
(1,2 \text { or } 3)\end{array}$ & $\begin{array}{l}\text { "Ex d", "Ex e", "Ex px", } \\
\text { "Ex py", "Ex pz", "Ex n" }\end{array}$ \\
\hline
\end{tabular}

Marks of the type of motor protection in Tab. 3 signify the following: "Ex d" stands for "flameproof enclosures", "Ex e" for "increased safety", "Ex p (x, y or z)" for "pressurized enclosures" and "Ex n" for "non sparking".

One of the main purposes of this work is to highlight the fact that performing only the basic tests can be inefficient in the detection of faults which can then become effective ignition sources in induction motors. It is the fundamental deficiency of the traditional approach to explosion protection, so the new approach is proposed in this paper.

\section{Proposed approach}

To identify the risks of further utilization of induction motors which have been in operation in hazardous areas for years, it is essential to perform specific tests in addition to the basic ones. This group of tests includes diagnostics of the rotor cage condition, stator winding, air gap, bearings, etc. Analysis of the rotor cage condition as the potential source of ignition is the basis of this research.

Only by performing tests and diagnostics from the first and the second group one can get a complete insight of the induction motor condition which can then be used for the overall risk assessment of the continued use of the motor in hazardous areas. A combination of those measures and tests is called the proposed approach in this paper. Due to the fact that basic tests are well known and can easily be found in literature, for example in [17] or [20], they are not part of this work. In this paper the proposed approach is illustrated in the research on hot surfaces as effective sources of ignition which can be caused by rotor cage faults, which is not recognised by the traditional approach.

Damage to an "Ex e" motor's rotor cage which can lead to an ignition source presents a special risk. Every source of ignition must acquire sufficient temperature $(T)$ and enough energy $(E)$ to become effective. This can be represented by Eq. (1) and Eq. (2):

$$
\begin{aligned}
& T>T_{\mathrm{p}} \\
& E>E_{\mathrm{p}}
\end{aligned}
$$

where $T_{\mathrm{p}}$ is the ignition temperature (for $E>E_{\mathrm{p}}$ ), and $E_{\mathrm{p}}$ is the ignition energy (for $T>T_{\mathrm{p}}$ ).

The approximate minimum ignition energy for some gases is shown in Tab. 4 [21]. Tab. 4 also shows their chemical formulae and volume explosive limits at atmospheric pressure of the mixture (101 $325 \mathrm{~Pa})$ when the mixture temperature is $20^{\circ} \mathrm{C}$ [20].

\begin{tabular}{|l|c|c|c|}
\hline \begin{tabular}{|l} 
Combustible \\
gas
\end{tabular} & $\begin{array}{c}\text { Chemical } \\
\text { formulae }\end{array}$ & $\begin{array}{c}\text { Volume } \\
\text { explosive limits } \\
/ \%\end{array}$ & $\begin{array}{c}\text { Minimum } \\
\text { ignition } \\
\text { energy / mJ }\end{array}$ \\
\hline Propane & $\mathrm{C}_{3} \mathrm{H}_{8}$ & $1,7 \div 10,9$ & 0,30 \\
\hline Methane & $\mathrm{CH}_{4}$ & $4,4 \div 17$ & 0,32 \\
\hline Hydrogen & $\mathrm{H}_{2}$ & $4 \div 77$ & 0,019 \\
\hline Acetylene & $\mathrm{C}_{2} \mathrm{H}_{2}$ & $2,3 \div 100$ & 0,019 \\
\hline
\end{tabular}

Tab. 5 lists minimum ignition temperature of some gases and vapours obtained by measurements according to the standardized method [20].

Table 5 Minimum ignition temperatures

\begin{tabular}{|l|c|}
\hline \multicolumn{1}{|c|}{ Combustible gas } & Minimum ignition temperature $/{ }^{\circ} \mathrm{C}$ \\
\hline Propane & 450 \\
\hline Methane & 595 \\
\hline Hydrogen & 560 \\
\hline Acetylene & 305 \\
\hline Gasoline (vapours) & 220 \\
\hline
\end{tabular}

The proposed approach was applied by this research to measure temperatures which occur in the rotor cage of an induction "Ex e" motor during fault conditions. Such faults (and potential resulting sources of ignition) possess sufficient ignition energy, which, therefore, was not the subject of analyses and tests.

\section{Experimental research \\ 4.1 Selection and preparation of the motor and the testing system}

Research on the heating was performed on an increased safety type of protection motor - Ex e II T1 $\mathrm{T} 3, t_{\mathrm{E}}=16 \mathrm{~s} / 16 \mathrm{~s} / 8,1 \mathrm{~s}$ (maximum permitted time under stalled rotor condition before exceeding the declared temperature classification), $I_{\mathrm{A}} / I_{\mathrm{N}}=6$ (ratio of the motor current under the stalled rotor conditions and the rated current), $47 \mathrm{~kW}$ rated power, $380 \mathrm{~V}$ rated voltage and 83 A rated current. The rated speed of the motor is 2960 $\min ^{-1}$.

The rotor cage is built of 34 copper bars connected by hard soldered shortcut rings. The cage construction represents the worst case in the light of explosion safety which was the reason for selecting it for the research [22]. A testing system, as shown in Fig. 5, is prepared to allow the thermal testing of the motor with the rotor stalled at different levels of voltage/currents.

This work includes rotor cage thermal tests of the bars and the ring of a motor in good condition, as well as tests of the bars and the ring at two levels of rotor cage damage. The damage description is given in Tab. 6 .

Detailed thermal measurements and possible detection of hot spots (in order to identify effective sources of ignition) were performed on the rotor in good 
condition, as well as on the rotor with level I and level II damage.

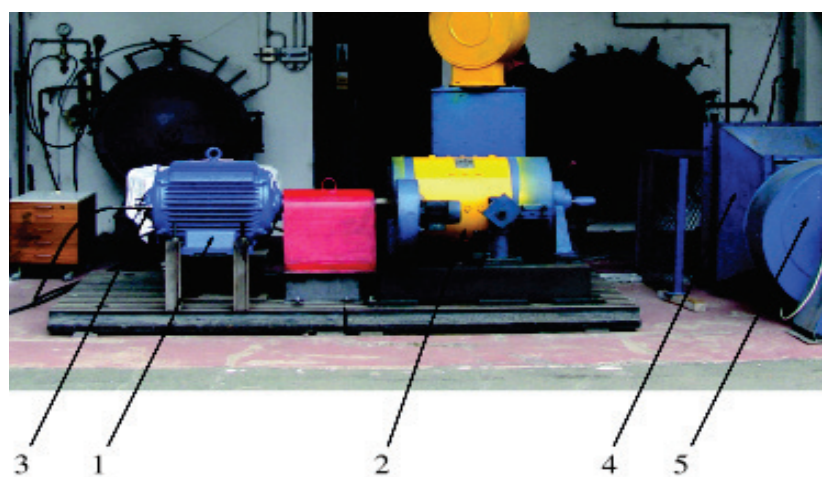

Figure 5 A system for thermal testing of the induction motor: 1 - motor tested, 2 - loading machine of the motor, 3 - test mixture inlet (not relevant for thermal testing), 4 - electrical load of the loading machine (heaters) and 5 - cooling fans for the heaters.

Table 6 Rotor cage damage

\begin{tabular}{|c|c|}
\hline $\begin{array}{c}\text { Damage } \\
\text { level }\end{array}$ & Damage description \\
\hline I & $\begin{array}{c}\text { Crack on bar No. } 7 \text { and cut } \\
\text { through bars No. 8 and 9 }\end{array}$ \\
\hline II & $\begin{array}{c}\text { Cut through bars No. 6, 10 and 11 } \\
\text { in addition to damage level I }\end{array}$ \\
\hline
\end{tabular}

The test equipment used for the thermal measurements on the motor (FLUKE Hydra Data Bucket and Hydra Series II) is shown in Fig. 6, while Fig. 7 shows positions of thermal sensors $(\mathrm{T}-\mathrm{Cu} / \mathrm{Cu}-\mathrm{Ni})$ for rotor thermal testing. Motor load current was measured by FLUKE True RMS Clamp Meter 337. The voltage at the motor terminals was measured by multimeter FLUKE True Multimeter 189. Ambient temperature was measured by RotronicHygrolog device.

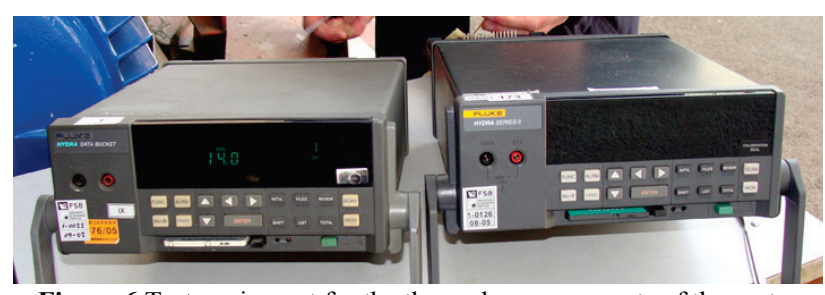

Figure 6 Test equipment for the thermal measurements of the motor

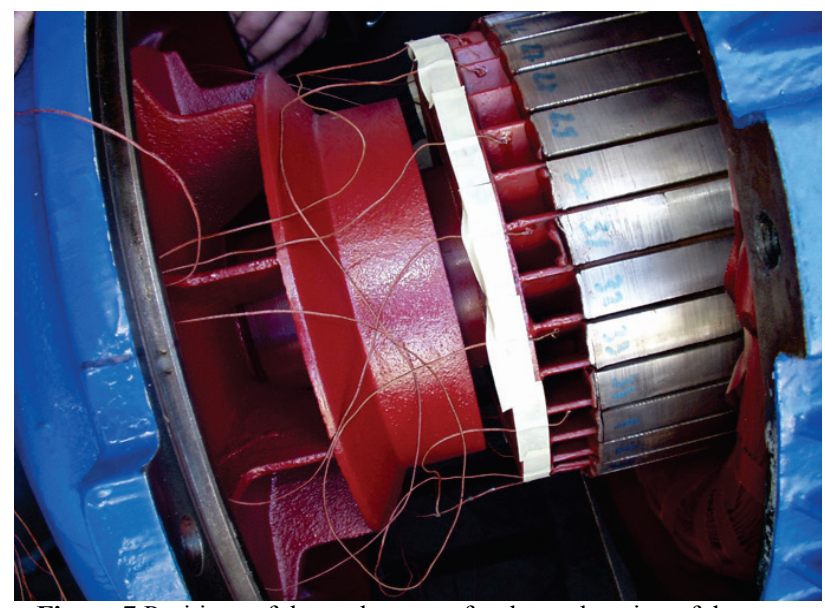

Figure 7 Positions of thermal sensors for thermal testing of the rotor

\subsection{Results of motor thermal tests 4.2.1 Rotor cage in good condition (with no damage)}

Thermal tests of rotor cage bars with no damage and thermal tests on the stator winding were conducted with the rotor at reduced voltage and stalled. In order to speed up the heating process, testing was initiated with the voltage reduced to $45,0 \mathrm{~V}$ and current of $54,4 \mathrm{~A}$, which were subsequently decreased to $21,6 \mathrm{~V}$ and $25,6 \mathrm{~A}$, causing the temperature curve to slow its increase (the final rate of temperature change less than $0,5{ }^{\circ} \mathrm{C} /$ hour). Ambient temperature during the measurement was between $13,6^{\circ} \mathrm{C}$ and $17^{\circ} \mathrm{C}$.

The results of thermal tests completed on the motor with no damage are shown in Fig. 8.

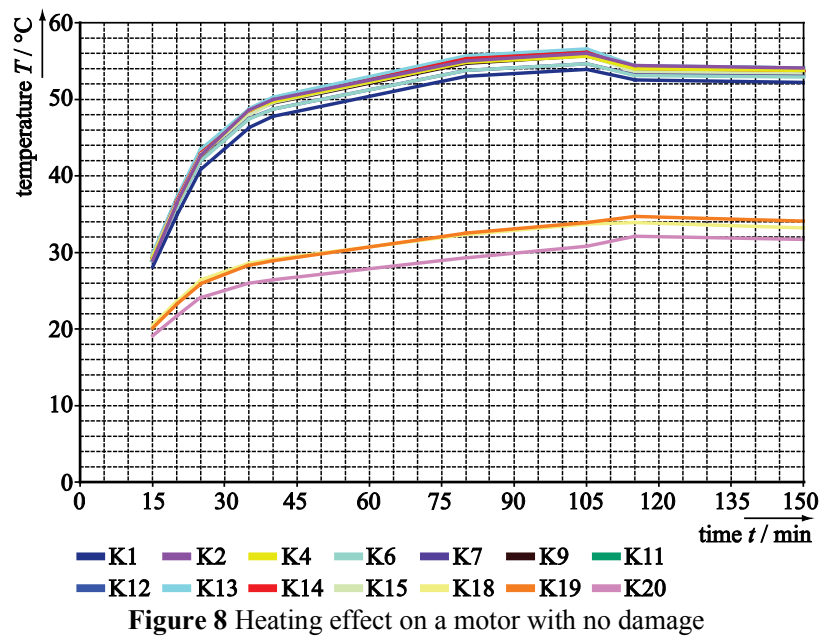

The temperature was measured on the rotor cage bars and the stator winding. Measuring channel marks $(\mathrm{K})$ of test equipment correspond to measurements on the following spots: $\mathrm{K} 1$ - bar 1, K2 - bar 3, K4 - bar 7, K6 bar 11, K7 - bar 13, K9 - bar 17, K11 - bar 21, K12 - bar 23, K13 - bar 25, K14 - bar 27, K15 - bar 29, K18 - stator winding, K19 - stator winding and K20 - stator winding.

\subsubsection{Level I damage on rotor cage}

Thermal tests on the bars of the rotor cage with level I damage and the stator winding with no damage were conducted with the rotor stalled. The first test was performed at the voltage reduced to $119,0 \mathrm{~V}$ and current of $140 \mathrm{~A}$. The second test was done at $200,0 \mathrm{~V}$ and $250 \mathrm{~A}$. Ambient temperature during the measurement was $6,0{ }^{\circ} \mathrm{C}$. Results of thermal tests completed on the motor with level I damage using the current of 140 A are shown in Fig. 9, while the results with $250 \mathrm{~A}$ are shown in Fig. 10.

The temperature was measured on rotor cage bars. Measuring channel marks $(\mathrm{K})$ of test instrument 1 and marks (C) of test instrument 2 correspond to measurements on the following spots: K2 - bar 7(C), K3 bar 7(B), K4 - bar 8(C), K5 - bar 8(B), C8 - bar 13(A), C9 - bar 23(A), C10 - bar 6(A) and C11 - bar 1(A).

Temperature sensors (thermal couples) on rotor bars, marked with an (A) following the number, were positioned at the part of the bar inside the rotor package (at the edge of the package close to a non-drive end). Thermal couples on rotor bars, marked with a (B) 
following the number, were positioned at the part of the damaged bar in the vicinity of the rotor package. Thermal couples on rotor bars, marked with a (C) following the number, were positioned at the part of the damaged bar in the vicinity of the rotor ring close to the non-drive end.

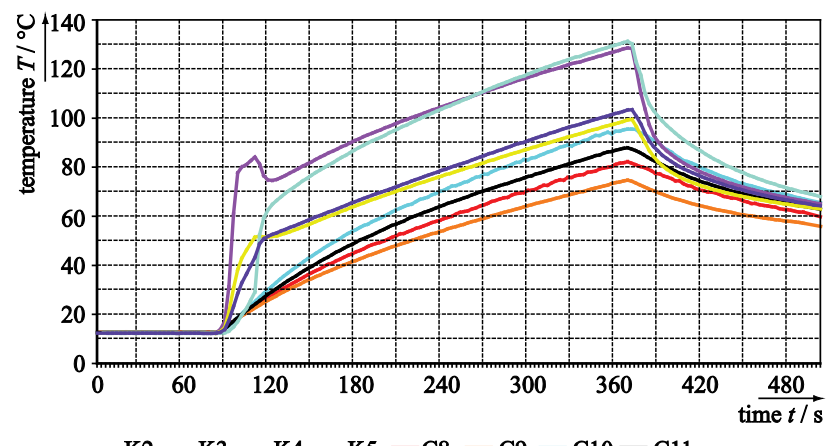

$-\mathrm{K} 2-\mathrm{K} 3-\mathrm{K} 4-\mathrm{K} 5-\mathrm{C} 8-\mathrm{C} 9-\mathrm{C} 10-\mathrm{C} 11$

Figure 9 Heating effect on the motor with level I damage and $140 \mathrm{~A}$

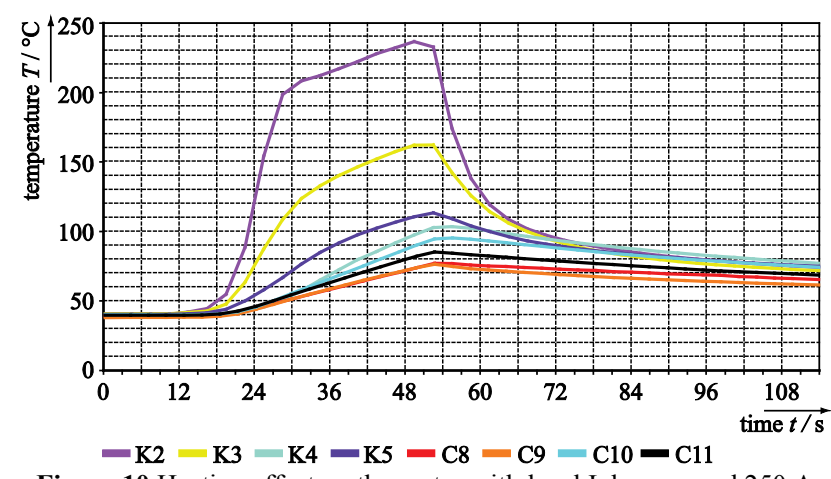

Figure 10 Heating effect on the motor with level I damage and $250 \mathrm{~A}$

\subsubsection{Level II damage on rotor cage}

Thermal tests on the bars of the rotor cage with level II damage and stator winding with no damage have been conducted with the rotor stalled. The first test was performed at the voltage reduced to $117,0 \mathrm{~V}$ and the current of $140 \mathrm{~A}$. The second test was done at 200,0 V and $250 \mathrm{~A}$. Ambient temperature during the measurement was $11,0{ }^{\circ} \mathrm{C}$. Results of the thermal tests completed on the motor with level II damage using the current of $140 \mathrm{~A}$ are shown in Fig. 11, while the results at $250 \mathrm{~A}$ are shown in Fig. 12.

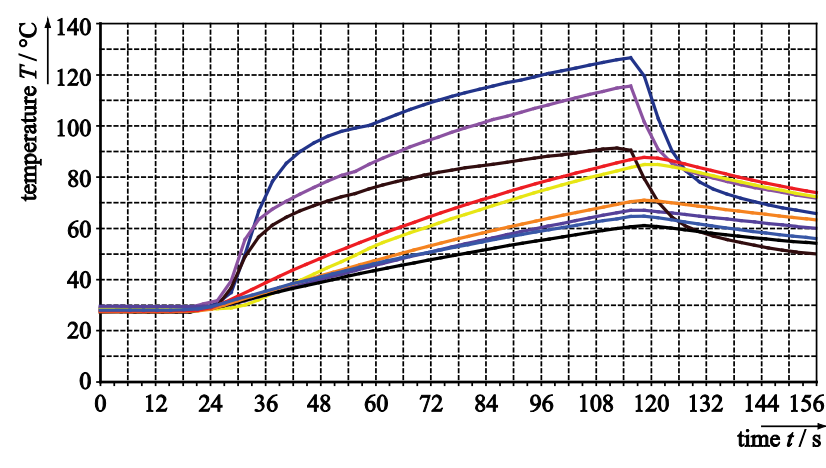

$-\mathrm{K} 1-\mathrm{K} 2-\mathrm{K} 3-\mathrm{K} 5-\mathrm{K} 6-\mathrm{C} 7-\mathrm{C} 8-\mathrm{C} 9-\mathrm{C} 10$

Figure 11 Heating effect on the motor with level II damage and $140 \mathrm{~A}$

The temperature was measured on the rotor cage bars and the ring close to the non-drive end. Measuring channel marks $(\mathrm{K})$ of test instrument 1 and marks $(\mathrm{C})$ of test instrument 2 correspond to the measurements on the following spots: K1 - bar 7(C), K2 - bar 6(C), K3 - bar 10(C), K5 - bar 1(A), K6 - bar 6(B), C7 - bar 23(A), C8 bar 13(A), C9 - ring in the vicinity of bar 7 and $\mathrm{C} 10$ - ring in the vicinity of bar 23 .

Thermal sensors (thermal couples) on rotor bars, marked with an (A), were positioned at the part of the bar in the vicinity of the ring close to the non-drive end. Thermal couples on the rotor, marked with a (B), were positioned at the part of the damaged bar in the vicinity of the rotor package, and those marked with a $(\mathrm{C})$ were positioned at the part of the damaged bar in the vicinity of the ring close to the non-drive end.

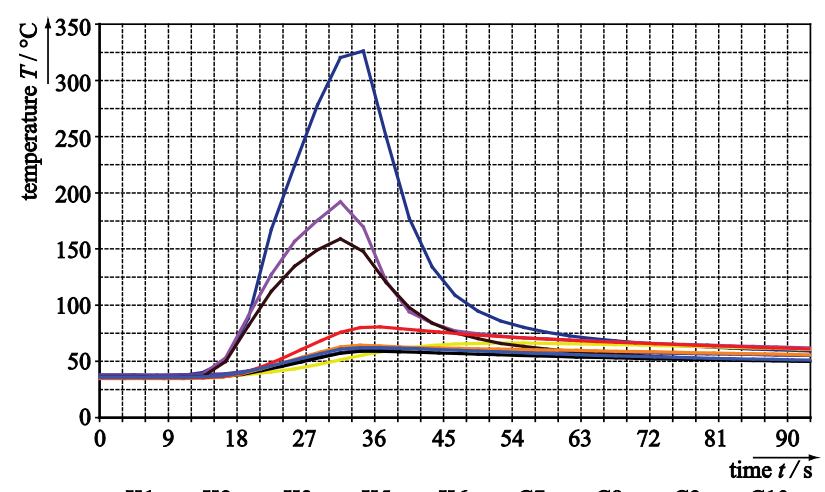

$-\mathrm{K} 1-\mathrm{K} 2-\mathrm{K} 3-\mathrm{K} 5-\mathrm{K} 6-\mathrm{C} 7-\mathrm{C} 8-\mathrm{C} 9-\mathrm{C} 10$

Figure 12 Heating effect on the motor with level II damage and $250 \mathrm{~A}$.

\section{Analyses of the measuring results}

Temperature measurements on the rotor cage under specific fault conditions show that it is possible to obtain temperature levels higher than those allowed by the temperature classification of the motor being tested. The motor has been certified for temperature class T3 (max. temperature $\leq 200{ }^{\circ} \mathrm{C}$ ). This is shown in Tab. 7. Tab. 7 shows results of the temperature measurement at the undamaged rotor bar (marked with $\mathrm{A}$ ) and in the vicinity of the damage on the rotor cage bar (marked with B). Temperatures $\mathrm{A}$ and $\mathrm{B}$ given in the table were measured simultaneously and at the same current value with the rotor stalled (simultaneous measurement was performed by the multichannel instrument). For damage levels I and II the table shows the results for current value of $250 \mathrm{~A}$, with a rotor blocked (voltage is reduced to $200 \mathrm{~V}$ ).

For the undamaged rotor cage an average value obtained by the measurement on all measured bars is listed. A thermal test of the undamaged rotor cage was conducted to verify the uniform distribution of heat at all bars which is clearly shown in Fig. 8. An absolute value of the undamaged rotor cage bars temperature is not of a major importance for this research.

Bar No. 7 reached the maximum temperature at level II damage, which was $338,2^{\circ} \mathrm{C}$. The temperature was not recorded by a multichannel instrument due to the limited sampling frequency (here a maximum temperature of $325,9^{\circ} \mathrm{C}$ was recorded). The temperature of $338,2^{\circ} \mathrm{C}$ was observed by the IR camera with continuous monitoring and recording. Maximum temperature at the location of the damage was measured after time $t_{\mathrm{E}}$ passed, which is $8,1 \mathrm{~s}$ for motor used in research and for T3 temperature class.

Although maximum temperatures were measured after time $t_{\mathrm{E}}$ passed (e.g. for level II damage the 
maximum temperature was measured $20 \mathrm{~s}$ after the reduced voltage was connected with the stalled rotor), this poses a direct risk because stalled rotor currents with reduced voltage are considerably lower than the currents at the rated voltage (stalled rotor current with the rated voltage of $380 \mathrm{~V}$ is $498 \mathrm{~A}$ ). The overload protection (related to $I_{\mathrm{A}}$ and $t_{\mathrm{E}}$ ) set to $498 \mathrm{~A}$ would not operate inside the timeframe of $t_{\mathrm{E}}$.

Table 7 Induction motor heating and the occurrence of hot surfaces (ignition sources)

\begin{tabular}{|c|c|c|c|}
\hline $\begin{array}{c}\text { Induction } \\
\text { motor } \\
\text { condition } \\
\text { (rotor cage) }\end{array}$ & $\begin{array}{c}\text { Measured } \\
\text { temperature } \\
\mathrm{A} /{ }^{\circ} \mathrm{C}\end{array}$ & $\begin{array}{c}\text { Measured } \\
\text { temperature } \\
\mathrm{B} /{ }^{\circ} \mathrm{C}\end{array}$ & $\begin{array}{c}\text { Maximum } \\
\text { allowed } \\
\text { temperature for } \\
\mathrm{T} 3 /{ }^{\circ} \mathrm{C}\end{array}$ \\
\hline Good & 54,3 & - & 200 \\
\hline $\begin{array}{c}\text { Damage level } \\
\text { I }\end{array}$ & 85,5 & 236,7 & 200 \\
\hline $\begin{array}{c}\text { Damage level } \\
\text { II }\end{array}$ & 59,9 & 338,2 & 200 \\
\hline
\end{tabular}

According to Annex A of IEC 60079-7 results of the thermal tests on the motor with a stalled rotor and reduced voltage shall be recalculated by using Eq. (3),

$$
\left(\frac{\Delta T_{\mathrm{rc}}}{\Delta T_{\mathrm{me}}}\right)=\left(\frac{U_{\mathrm{n}}}{U_{\mathrm{rd}}}\right)^{2}
$$

where $\Delta T_{\mathrm{rc}}$ is recalculated overtemperature with rotor stalled and rated voltage connected, $\Delta T_{\mathrm{me}}$ is measured overtemperature with rotor stalled and reduced voltage, $U_{\text {rd }}$ is reduced motor voltage and $U_{\mathrm{n}}$ is rated motor voltage $(380 \mathrm{~V})$.

Tab. 8 shows overtemperatures of the damaged rotor cage (level II damage) obtained by the measurement and the recalculation in accordance with Eq. (3) using different reduced voltage levels and with the rotor stalled. All overtemperatures were measured at the damaged bar No. 7 and $8 \mathrm{~s}$ after the connection of the voltage with the rotor stalled.

Table 8 Results of the damaged bar 7 overtemperature measurement and recalculation

\begin{tabular}{|c|c|c|}
\hline \multicolumn{3}{|c|}{ measurement and recalculation } \\
\hline$U_{\mathrm{rd}} / \mathrm{V}$ & $\Delta T_{\text {me }}$ after $8 \mathrm{~s} / \mathrm{K}$ & $\Delta T_{\mathrm{rc}}$ after $8 \mathrm{~s} / \mathrm{K}$ \\
\hline 119 & 5 & 326 \\
\hline 200 & 36 & 367 \\
\hline
\end{tabular}

For realistic technical application the measured and recalculated values (for the three voltage levels with the rotor stalled) show an acceptable level of compliance with Eq. (3).

For technical application an acceptable level of compliance with Eq. (3) is also shown with the ratios of the measured overtemperatures compared to the ratios of voltages applied during the measurement.

\section{Conclusion}

With the results obtained and taking into account the maximum ambient temperature, standardised to $40{ }^{\circ} \mathrm{C}$, and the observed discrepancy/dissipation of the results obtained by recalculation and measurement shown in Tab.
8 , we can draw the important conclusion that damage levels I and II with the stalled rotor and the rated voltage applied (which is the anticipated situation in abnormal but realistic conditions) represent the effective sources of ignition of explosive atmospheres made by flammable media having an ignition temperature higher than the declared temperature class $\mathrm{T} 3\left(200^{\circ} \mathrm{C}\right)$, even in conditions when a required overload protection of "Ex e" motor is applied and will operate inside the timeframe of $t_{\mathrm{E}}(8,1 \mathrm{~s})$.

Research has shown that damage to the rotor cage is, in most cases, not detectable in the normal operation of the motor, nor is it required that the overload protection of an "Ex e" motor recognises any damage. Furthermore, thermal tests on the rotor and on the motor in general during the lifetime of the motor are not required by today's conception/methodology of explosion protection.

This research confirmed the initial assumption of the proposed approach according to which the traditional or basic tests on the "Ex e" type of explosion protected motor can be inefficient in the detection of faults which can become effective ignition sources in the exploitation of induction motors. The above presents the fundamental deficiency of the traditional approach to explosion protection. In order to detect such faults it is necessary to apply diagnostic tests.

For future research in this area it would be useful to analyse different diagnostic methods and their reliability with identified rotor cage faults.

Furthermore, it is strongly recommended for future work that experimental verification of the efficiency of detected hot spots should be conducted (hot surfaces as ignition sources) in realistic conditions with an explosive mixture present.

\section{References}

[1] Gavranić, I.; Ban, D.; Žarko, D. Explosion protected electrical drives - risk assessment and technical diagnostics. // Proceedings of the $13^{\text {th }}$ International Power Electronics and Motion Control Conference / Poznan, 2008, pp. 833840. https://doi.org/10.1109/epepemc.2008.4635368

[2] Gavranić, I. Risk assessment of electrical drives application in hazardous areas. / PhD, University of Zagreb, Zagreb, Croatia, 2010.

[3] Szentirmai, L.; Szarka, T. Electrical drives improvement for industry application. // Proceedings of the $16^{\text {th }}$ International Conference on Electrical Drives and Power Electronics / The High Tatras, 2007, pp. 126-131.

[4] Thomson, W. T. A review of on-line condition monitoring techniques for three - phase squirrel - cage induction motors - past present and future. // Proceedings of the IEEE 1999 International Symposium on Electrical Machines, Power Electronics and Drives / Gijon, 1999, pp. 3-18.

[5] Lanphier, M.; Sen, P. K.; Nelson, J. P. An update on surge protection of medium voltage motors: a comparison of the standards and application. // Proceedings of the $4^{\text {th }}$ Petroleum and Chemical Industry Conference Europe Electrical and Instrumentation Applications / Paris, 2007, pp. 3-10. https://doi.org/10.1109/pciceurope.2007.4353996

[6] Glowacz, W. Diagnostics of induction motor based on spectral analysis of stator current with application of backpropagation neural network. // Archives of Metallurgy and Materials. 58, 2(2013), pp. 559-562. https://doi.org/10.2478/amm-2013-0037 
[7] Ngote, N.; Guedira, S.; Cherkaoui, M.; Ouassaid, M. A new hybrid "Park's vector - time synchronous averaging" approach to the induction motor - fault monitoring and diagnosis. // Journal of Electrical Engineering \& Technology. 9, 2(2014), pp. 559-568. https://doi.org/10.5370/JEET.2014.9.2.559

[8] Ha Hwang, D.; Woo Youn, Y.; Hwa Kim, Y. Robust diagnosis algorithm for identifying broken rotor bar faults in induction motors. // Journal of Electrical Engineering \& Technology. 9, 1(2014), pp. 37-44. https://doi.org/10.5370/JEET.2014.9.1.037

[9] Glowacz, A. Diagnostics of rotor damages of three-phase induction motors using acoustic signals and SMOFS-20EXPANDED. // Archives of Acoustics. 41, 3(2016), pp. 507-515. https://doi.org/10.1515/aoa-2016-0049

[10] Glowacz, A. Diagnostics of DC and induction motors based on the analysis of acoustic signals. // Measurement Science Review. 14, 5(2014), pp. 257-262. https://doi.org/10.2478/msr-2014-0035

[11] Glowacz, A. Diagnostics of induction motor based on analysis of acoustic signals with the application of eigenvector method and $\mathrm{K}$ - nearest neighbor classifier. // Archives of Metallurgy and Materials. 57, 2(2012), pp. 403-407. https://doi.org/10.2478/v10172-012-0039-y

[12] Kowalski, C. T.; Wierzbicki, R.; Wolkiewicz, M. Stator and rotor faults monitoring of inverter-fed induction motor drive using state estimators. // Automatika. 54, 3(2013), pp. 348-355. https://doi.org/10.7305/automatika.54-3.167

[13] Ngote, N.; Ouassaid, M.; Guedira, S.; Cherkaoui, M. On the detection of induction-motor rotor fault by the combined "Time synchronous averaging-discrete wavelet transform" approach. // Journal of Electrical Engineering \& Technology. 10, 6(2015), pp. 2315-2325. https://doi.org/10.5370/JEET.2015.10.6.2315

[14] Medoued, A.; Lebaroud, A.; Laifa, A.; Sayad, D. Classification of induction machine faults using frequency representation and particle swarm optimization. // Journal of Electrical Engineering \& Technology. 9, 1(2014), pp. 170-177. https://doi.org/10.5370/JEET.2014.9.1.170

[15] Vaimann, T.; Belahcen, A.; Kallaste, A. Changing of magnetic flux density distribution in a squirrel-cage induction motor with broken rotor bars. // Eletronika ir Elektrotechnika. 20, 7(2014), pp. 1392-1215. https://doi.org/10.5755/j01.eee.20.7.8018

[16] Glowacz, A. Recognition of acoustic signal of induction motor using FFT, SMOFS-10 and LSVM. // Eksploatacja I Niezawodnosc - Maintenance and Reliability. 17, 4(2015), pp. 569-574. https://doi.org/10.17531/ein.2015.4.12

[17] Directive 94/9/EC of the European Parliament and of the Council of the European Communities, 1994.

[18] Directive 2014/34/EU of the European Parliament and of the Council of the European Union, 2014.

[19] Directive 1999/92/EC of the European Parliament and of the Council of the European Communities, 1999.

[20] Standards IEC 60079, Electrical Apparatus for Explosive Gas Atmospheres, IEC.

[21] Marinović, N. Electrotechnology in Mining. Elsevier Science Publishing Company Inc., Amsterdam, 1990.

[22] Gavranić, I. Implementation of electro motors in explosive environments - experimental investigations of fire risk. // Sigurnost/Safety. 51, 3(2009), pp. 207-214. (article in Croatian with an abstract in English).

\section{Authors' addresses}

Ivica Gavranić, Ph. D.

Agency for Explosive Atmospheres

Industrijska ulica 25, 10431, Sveta Nedelja, Croatia i.gavranic@ex-agencija.hr

Mario Vražić, Ph. D., Associate Professor University of Zagreb,

Faculty of Electrical Engineering and Computing Unska 3, 10000 Zagreb, Croatia

mario.vrazic@fer.hr

Damir Sumina, Ph. D., Assistant Professor

University of Zagreb,

Faculty of Electrical Engineering and Computing

Unska 3, 10000 Zagreb, Croatia

damir.sumina@fer.hr 